\title{
LEGAL SYSTEM, LEGALITY, AND THE STATE: AN INTER-INSTITUTIONAL ACCOUNT
}

\author{
Keith CULVER* \\ Michael GIUDICE**
}

Resumen:

En este artículo los autores se proponen explorar diversos retos que enfrentan los teóricos analíticos del derecho contemporáneos, los cuales han aceptado que una perspectiva estatista del sistema jurídico y de la legalidad -introducida por H. L. A. Hart- es fundamental como punto de partida en la teoría. Los autores sostienen que este enfoque contiene problemas explicativos internos que limitan su capacidad para explicar fenómenos jurídicos prima facie novedosos que no se ajustan a la experiencia paradigmática de un derecho-estado. Los autores reformulan el enfoque analítico mediante la introducción de las bases de lo que denominan una "teoría de la legalidad inter-institucional", esto es, una teoría de la legalidad derivada de una noción moralmente neutral, descriptiva y explicativa del sistema jurídico como un sistema de instituciones jurídicas. Esta teoría permite, además, explicar los fenómenos jurídicos prima facie novedosos que identifican los autores; y concluir que si bien los enfoques anteriores hacia el sistema jurídico y la legalidad de los teóricos analíticos estuvieron históricamente en lo correcto al tomar como punto de partida el ejemplo de un sistema jurídico municipal, ese ejemplo y punto de partida han dejado de ser relevantes, dicho ejemplo y punto de partida no resulta suficiente, por lo que la explicación de la legalidad dentro de los confines del Estado no es suficiente para una explicación general de la legalidad.

* University of New Brunswick.

** York University. 


\section{CULVER / GIUDICE}

Abstract:

We aim in this paper to explore several related challenges to contemporary analytical legal theorists who accept as theoretically foundational the state-based view of legality and legal system advanced by H.L.A. Hart. We contend that this approach contains internal explanatory problems which limit the view's capacity to account for novel prima facie legal phenomena outside the typical experience of the law-state. We supplement the analytical approach by advancing the rudiments of what we call an 'inter-institutional theory of legality,' a theory of legality derived from a morally-neutral, descriptive-explanatory picture of legal system qua system of legal institutions. Our theory additionally enables us to account for the novel prima facie legal phenomena we identify, and to conclude that while prior analytical legal theorists' approaches to legality and legal system were historically right to depart from the example of the municipal legal system, that example and departure point are no longer most salient, so explanation of the legality within the state is no longer sufficient as a general explanation of legality. 
SummarY: 1. New Phenomena. 2. Circularity and Indeterminacy. 3. An Inter-Institutional Theory. 4. Legality and the De-Centred Law-State. 5. Conclusion. Bibliography.

Analytical legal theory has long taken as its central focus the experience of the law-state, and the success of analytical theories of law has been measured by their ability to explain the phenomenon of the law-state. Yet this focus and conception of success may be forced to change as the place of the law-state in our experience of law is changing - from the United Kingdom's devolution of power to Scotland, to the European Union's consideration of a shared constitution, and the rise of supra-national legal institutions such as the International Criminal Court. The goal of this article is to show that analytical legal theory faces insurmountable explanatory problems which prevent it from responding adequately to the theoretical challenges posed by the flourishing of novel forms of legal order, and to provide the basis of an adequate theoretical response to those novel phenomena while remaining within at least some of the commitments and virtues of the analytical approach. As we develop our argument we do not propose to advance evidence from every purported instance of legality outside conventional law-states. Nor do we propose to encounter every variant of analytical theory. We aim to identify several categories of prima facie legal phenomena deserving explanation and inclusion or rejection by analytical theories of law as legal phenomena, and to supply a particular line of argument against the capacity of both the dominant historical arguments and novel variants to account for those phenomena. We offer a remedy to the shortcomings of analytical legal theory in the form of an inter-institutional theory of legality which develops an account of legal order from assessment of intensity of mutual reference among social institutions whose status as legal institutions is demonstrated by their use of functionally-related families of pe- 
remptory, content-independent norms. Our argument is intentionally gestural and non-comprehensive as we are tackling a large problem in only a little space. ${ }^{1}$ The merit of our paper lies, then, in the balance between our criticisms of prevailing analytical approaches, and the plausibility of the alternative we begin to build here.

The organization of our argument follows our motivation. Since we aim ultimately to contend that novel phenomena present an unanswerable challenge to dominant analytical approaches to characterization of legality, our first step is to display the phenomena. Next, we elaborate the reasons why the influential approach departing from the work of H. L. A. Hart cannot face these phenomena. Finally, we present the rudiments of our inter-institutional theory of legality.

\section{New Phenomena}

In what follows we present prima facie legal phenomena under four admittedly provisional categories which rely for their utility on their conventional meaning within law, political science, and legal theory. We identify and discuss: intra-state legality, trans-state legality, supra-state legality and super-state legality, capturing a range of norms and normative orders often spoken of as international law. It should be emphasized again that while we write here of these phenomena as exhibiting "legality", we do so only suggestively, as part of our contention that they exemplify social phenomena which pose a serious challenge to the explanatory adequacy of contemporary analytical legal theory.

\subsection{Intra-State Legality}

Perhaps the most intuitively challenging instances of prima facie legality are found within the law-state, yet none-

1 We take up more fully the questions and development of our inter-institutional theory in our book, Legality's Borders (manuscript on file with authors). 
theless appear to be meaningfully independent of the lawstate and so deserve recognition as 'intra-state' forms of legality. Far from the relatively familiar context of non-state legality in the emergence of international law out of the agreements of states, intra-state legality is systemic in ways sometimes characterized as arrangements of divided sovereignty, where sovereignty is internally shared yet externally united in foreign affairs, treaty-making, and other activities. Other forms of sovereignty-sharing may extend beyond conceptions of divided sovereignty into new orders in which legal orders do not abut but overlap one another.

Distributed governance arrangements are likely the most familiar intra-state devices for creation of what are sometimes regarded as subsystems of law, a relinquishing of centralized governance authority which nonetheless stops short of division of sovereignty. In these arrangements historically core legal institutions distribute their authority to relatively distant legal institutions within the system, whether reformed extant institutions or new institutions. Typically this distribution is undertaken to locate decision-making within institutions best suited to making particular decisions - whether geographically or experientially or financially or in some other way best suited. Shared governance is a less familiar, yet increasingly evident form of governance within the law-state involving collaboration between traditionally or historically central legal institutions and other social organizations of varying complexity and institutionalization, contributing in various plainly evident ways to formation and variation of legal norms. From shared governance we may now be moving to overlapping, relatively independent legal orders of a new form- perhaps in spite of insistence to the contrary on the part of the central agents in these new orders.

In Canada, for example, federal and provincial governments face complex governance tasks with respect to indigenous 'First Nations' peoples, several of whom are still in the process of negotiating land claims treaties, denying 
Canada's authority and acting in a fashion similar to sovereign states while for the most part remaining de facto within the authority of the Canadian law-state. The justice of First Nations claims and the aftermath of colonial practices has left federal and provincial governments very sensitive to the complexity of governance of related issues. One result has been the negotiation of methods of mutual relation between Government of Canada and First Nations authorities regarding matters such as taxation. The nature of this relation is complex, yet whatever final analysis reveals, it is worth considering the possibility that new forms of legal order are being forged. The Government of Canada itself acknowledges in the terms of its announcement in the Canada Gazette that the First Nations Tax Commission is "a shared governance organization which requires that appointments to the governing body be made by both the Government of Canada and at least one other government or organization". ${ }^{2}$

2 See http://canadagazette.gc.ca/partI/2006/20060701/html/regle7-e.html Canada Gazette, Vol. 140, No. 26 - July 1, 2006. As the Canada Gazette explains the role:

Specifically, the FNTC was created to

- Assume authority for the approval of First Nation property tax laws made under the Act;

- Provide professional and objective assessments of First Nation property taxation under the Act;

- Prevent and minimize the costs of disputes by providing a mechanism for hearing the concerns of affected parties under the Act and for promoting the reconciliation of the interests of First Nations and taxpayers;

- Set standardized administrative practices for First Nation real property tax administrations created under the Act and provide training to ensure standards are achieved;

- Provide education in order to raise awareness of the benefits of First Nation taxation between First Nations and the rest of the country; and

- Advise the Minister on policy issues relating to the implementation of First Nation property taxation powers and on any matter or policy put to it by the Minister.

The FNTC is a shared governance organization which requires that appointments to the governing body be made by both the Government of Canada and at least one other government or organization. In the case of the FNTC, nine commissioners are selected by the Governor in Council on behalf of the Government of Canada, with the remaining commissioner appointed by a body established pursuant to subsection 20(3) of the Act. The First Nations Tax Commissioner Appointment 
There are of course a variety of ways of interpreting the force of "shared governance" in this situation and we leave unaddressed for the moment the question of whether First Nations possess sources of law giving them the capacity to participate meaningfully in some kind of sovereignty-like division, jointness or shared authority. For now it is enough to note that the phenomena pose difficulties for the explanatory role of a key tool of analytical legal theory: the officialbased rule of recognition which constitutes and distinguishes a discrete legal system from other social norms and systems. The rule's application is stretched beyond credulity if we say that what marks the legality and systematic nature of this interaction is incorporation of First Nations authorities by Canadian officials' recognition of them. The nature of the relation simply does not bear this out, to the extent that the Government of Canada itself represents the relation as one of shared governance between distinct governments. An adequate theoretical understanding of this situation may need to reach beyond the law-state model of legality and legal system to understand the special characteristics of intra-state legal orders which abut or overlap in various ways the range of other legal orders with which they interact. In short, an adequate theory of law must be able to answer the question "what is the relation between First Nations' legal order and the legal system of Canada?" Whatever the answer, it cannot simply presume that First Nations' claims and experience must be read through the lens of the extant and dominant Canadian law-state.

Regulations, made pursuant to paragraph $140(a)$ of the Act, identify the NLC as the body to appoint the additional commissioner to the FNTC.

Renowned for its expertise in promoting First Nation law, the NLC is a research centre within the University of Saskatchewan. It is responsible for the Program of Legal Studies for Native People. This program has been widely recognized for its role in increasing Aboriginal representation in the legal profession. The NLC also publishes the Canadian Native Law Reporter and since 1997, the First Nations Gazette. The First Nations Gazette is similar to the Canada Gazette and has been instrumental in improving the accessibility of First Nation laws, maintaining confidence in First Nation governments, and improving First Nation taxpayer relations. 


\subsection{Trans-state Legality}

Equally challenging, yet significantly different legal phenomena are found in situations where apparently non-state agents function like state agents in making general agreements outside the state which nonetheless bind citizens within the state. In situations of this kind, norms claiming peremptory, content-independent force arise as a result of practice or convention and are generally recognized as holding that force without reference to authorization of those norms by any particular law-state.

Our example is taken from the complex and increasingly important area of ocean resource governance, and more specifically, in regulation of fishing of salmon which migrate across state boundaries and international waters. The Greenland Conservation Agreement provides for a seven year moratorium on commercial, non-subsistence salmon fisheries in Greenland's territorial waters, from the 2007 season forward. ${ }^{3}$ This agreement extends the practice established by a 2002 moratorium. The agreement is signed by the "Atlantic Salmon Federation (ASF) of North America, the North Atlantic Salmon Fund (NASF) of Iceland, and the Organization of Fishermen and Hunters in Greenland (KNAPK), three non-governmental organizations..." and “...has been endorsed by the Greenland Home Rule Government which will help enforce it...". ${ }^{4}$ Several aspects of this agreement are relevant to analytical theories of legality, and their inclusion or exclusion of this phenomenon as an instance of legality or part of a legal order.

In assessing whether the moratorium might represent a legal norm or part of a legal order, it is significant that its proponents are neither governmental bodies nor representatives of government; in fact, the independence of this agreement from the law-state and international law goes much further. The Atlantic Salmon Federation draws its

3 http://www.asf.ca/news.php?id=99.

4 Idem. 
membership from both the United States and Canada and as a transboundary non-government organization is beholden to neither government. The Home Rule Government of Greenland is a devolved authority of the Kingdom of Denmark and lacks authority to enter into international treaties. These and the other proponents have entered into an agreement which grows out of an agreed practice, relying on social pressure within this group for its effectiveness and having no reference to the laws of any state jurisdiction as the laws of the agreement or the legal locus of dispute resolution with respect to the agreement. The agreement nonetheless extends an effective, established moratorium on commercial salmon fishing in Greenland's waters, to the extent that where ten years ago 600 license holders fished those waters, now there are none.

A state- and official-based analytical approach interprets this situation in a particular way: the agreement-derived obligation applying to all salmon fishers in Greenland's waters is a legal norm insofar as the Greenland Home Rule government has enacted this norm or endorsed it by authoritative certification, out of the urging of NGOs, and under the authority granted it by the Kingdom of Denmark to govern natural resources. The precise contours of this norm can be assessed by observation of how Greenland's officials in fact handle application of the norm. Little more need be said about this situation on the state-based analytical approach, because the NGOs are just that and so are not parties to an international treaty, and the Greenland Home Rule government is simply exercising its devolved powers.

This conventional analytical view of course expresses a plausible understanding of the situation. Yet it seems to us that a kind of distorting selectivity of emphasis is evident, and that selectivity points to shortcomings in an approach which presumes that a justified ascription of legality to some state of affairs must be a statement about membership in a system of norms associated with an authorizing law-state. In seeking a state-based rule of recognition to explain the phe- 
nomena, it seems the conventional view obscures the special formative role of the NGOs in the agreement, and in turn mistakenly underestimates the contri- bution of the Greenland Home Rule government in reaching an agreement which falls short of an international treaty, yet seems to be something other than simple incorporation into Greenland law of normative content presented by lobbying from NGOs from within and without Greenland. The effectiveness of the moratorium and its independence from law-states resembles the emergence of a legal order or subsystem from practice even as description of the situation in these terms might be surprising to some of the participants. This zone of interstitial, transboundary prima facie legality might, of course, be affected by Danish, Canadian or US governments' activities in international treaties in this area, but this is a familiar matter: not all legal norms are of equal force, nor are all legal orders, systems and subsystems of equal force.

As with the case of self-governance in Canada, we are left with a puzzle: what is the legality of effective peremptory norms which are formed by the secondary rules of no particular system? More simply, what tells us whether these social phenomena are legal or non-legal, and if so, their system membership and how that membership matters to their legality? And again as with the case of intra-state legality discussed above, whatever the answer to the question, it cannot simply presume that what appear to function as legal norms must have state-based origins.

\subsection{Supra-national legality: the puzzle of the European Union}

The preceding example of non-state legality mentioned a familiar feature of international law - that its existence depends largely on the consent of states. This arrangement preserves the sovereignty of states as a fundamental norm of international law while grounding the force of international legal obligations in the will of states. Voluntary agree- 
ment of the sort familiar from international law undoubtedly lies at the historic foundation of the European Union; yet as the Union has evolved it has come to claim that it represents a new legal order, neither a super-state nor an intergovernmental association. ${ }^{5}$ But what is that legal order? And what is the relation of that order to explanations of legality as fundamentally systemic in a sense best evident in the law-state? Julie Dickson usefully suggests that the puzzling nature of the European Union can be brought out by asking an intuitively but misleadingly simple question: how many legal systems are there in the EU? ${ }^{6}$ As Dickson notes, there are several possible answers: one legal system for every member-state; one legal system for every member-state plus one additional European legal system; or only one, super-European legal system. If there is more than one system $-i$. e. more than just one super-European legal system - how are legal theorists to characterize the relations between the systems? In particular, since both member-state courts and the European Court of Justice have claimed supremacy of final authority to interpret and apply European law, can we view either member-state legal systems or a European legal system as in some meaningful sense derivative, subordinate, or part of the other(s)? Or does this puzzle point us back to giving more serious consideration to the possibility that the European Union's claimed "new legal order" really is something new and different, not usefully reduced to talk of legal system?

The answers to all of these questions require prior answers to the question of the nature of legal system and the edges of a given legal system. What is also clear, however, is that a search for a rule of recognition for the European Union will not be of much help. Whatever those answers are, an official-based rule of recognition will likely not be p. 12 .

5 Van Gend en Loos v. Nederlandse administratie der belastingen [1963] ECR 1,

6 Dickson, "How many legal systems?: Some puzzles regarding the identity conditions of, and relations between, legal systems in the European Union", Problema, this issue. 
among them. Questions raised previously must be pressed again regarding the existence of such a rule and its explanatory value. Are there legal officials of the European Union, perhaps minimally the judges of the European Court of Justice? If a member-state's constitutional court enforces a European law which derives from a European treaty, are its officials to count as European or Member-State officials? Little ground is gained by simply "bootstrapping" from the presupposition that legality's foundational unit is the state, since such a view is precisely what gives rise to the puzzling aspects of legality of and within the European Union as we ask whether its new legal order is one or many. Here it seems to us that legal theorists such as Neil MacCormick are right to think that European law is inadequately theorized, not just because we lack answers to these questions, but more importantly because it is likely we lack the theory required to answer them. ${ }^{7}$

\subsection{Super-State Legality: claims to universality in peremptory jus cogens norms}

In mentioning the role of states' consent in the existence of international law we omitted identification of a further element of international law: the relatively small set of jus cogens or peremptory general norms of international law. These norms purport to bind states and their authorities independently of any prior consent: both historic and newly created law-states now appear everywhere subject to a sort of substrate of general, peremptory norms which claim to form part of a universally supreme system. ${ }^{8}$ These norms

7 MacCormick, Questioning Sovereignty, Oxford, Oxford University Press, 1999

8 Jus cogens, or peremptory norms of general international law, is clearly defined in article 53 of the Vienna Convention on the Law of Treaties (1969):

A treaty is void if, at the time of its conclusion, it conflicts with a peremptory norm of general international law. For the purposes of the present Convention, a peremptory norm of general international law is a norm accepted and recognized by the international community of States as a whole as a norm from which no dero- 
have more recently been employed to bind the leaders of states, who might dispute its capacity for application to them, as Slobodan Milosevic, former President of Serbia and Yugoslavia, famously did throughout his trial. ${ }^{9} \mathrm{~A}$ now-familiar range of jurisprudential questions emerges: is the existence of jus cogens demonstration that there is one global legal system, in which each law-state is but a subsystem? What distinguishes one subsystem from another? Or are peremptory international norms part of some non-systemic international legal order instead incorporated universally into otherwise separable state systems, so we have "one" international law inside the 'many' law-states? Or something else?

\section{CiRCULARITY AND INDETERMinACY}

We have so far offered only an introductory diagnosis of the problems facing analytical legal theorists keen to use Hart's theory of municipal law to explain novel phenomena. In this section we deepen that criticism and argue that analytical theorists following Hart's lead have failed to recognize that available accounts of the nature of legal officials those whose intentional practice gives rise to the existence and reaches of a rule of recognition - are either circular or indeterminate, depriving the rule of recognition of content and limiting its explanatory value. The problem of circularity refers to the burden of identifying legal officials without presupposing a notion of legal validity, which is simply the set of criteria of membership in a legal system practised by its officials. The problem of indeterminacy refers to the burden of identifying which sorts of activities or exercises of power in a legal system distinguish officials from non-officials. The shortcomings of analytical approaches to characterization

gation is permitted and which can be modified only by a subsequent norm of general international law having the same character.

9 See, e. g, http://news.bbc.co.uk/2/hi/uk_news/wales/1420561.stm. Accessed 7 April 2008. 
of officials tend to unravel the wider analytical account of legal system. If our argument is plausible, analytical approaches to legal system which depend on the rule of recognition are open to the charge that they are little more than a coherent conceptual framework whose viability as an explanation of major features of actual social life must be doubted to the extent that their connection to actual social life is unexplained, or at best explained in folk terms inadequate for the ambitions of a descriptive-explanatory philosophical theory of law.

\subsection{Officials by Office and Attitude}

Hart's theory of law offers many advances over John Austin's command theory of law. Hart showed with exceptional clarity that a theory of law constructed from concepts such as a social rule, the internal point of view, content-independent reason, and union of primary and secondary rules offers a far better explanation of life under law than a theory of law constructed out of the concepts of order, threat, sanction, habit of obedience, and legally unlimited sovereign. In place of the notion of a legally unlimited sovereign Hart supposes we ought to think in terms of rules of office, whereby official positions, with their constitutive duties and powers, enjoy legal authority independently of the particular persons who contingently occupy those positions. Rules of office and rules of succession explain the continuity of legal systems through changes in legislators and governments and also explain the persistence of laws long after their creators have died. Yet beyond the assertion that legal officials exist by virtue of special rules of office and succession, Hart offered little to explain which rules identify who is to count as a legal official, nor did he take any significant steps towards offering a philosophical explanation of what a legal official is.

Hart supposes legal officials can be identified and distinguished from other holders of social office in the same way 
that legal norms can be distinguished from other norms. A detached observer can simply look to see which rules of office are recognized and practiced in the legal system. Central cases of legal officials are deceptively easy to find. They include judges, lawyers, legislators, police, and immigration officers, among others. There is, however, an immediate problem with an account of officials which does no more than list examples and explain their status as officials by claiming that legal officials are those who occupy their positions by special rules of office, succession, and competence. Rules of office identify who is to count as an appellate judge, state lawyer, police officer, provincial legislator, immigration officer, but not who is to count as a "legal official". ${ }^{10}$ This is perhaps to be expected as particular legal systems have an interest in identifying specific legal officials for the specific purposes of those legal systems, but no need for a general account of the nature of officials. Philosophers of law pursuing a general jurisprudence are nonetheless left with a problem: without an account of the shared features which elucidate and explain the genus "legal official", we are left basing what purports to be a comprehensive, general jurisprudence on a fragmented collection of species-level accounts of judicial practices, prosecutorial practices, police practices, and so on. This situation is of course undesirable: while we might justifiably develop a comprehensive general jurisprudence on less than a complete description of all prima facie legal phenomena, we cannot do so with any confidence in the result in the absence of a clear account of how we have gathered descriptions of how much of that phenomena - or at any rate a process rather more rigorous than simply assuming that we have in hand the descriptive data we need.

We can readily demonstrate the circularity of the view that the legality of legal officials can be grounded in the

10 For similar reasons an answer cannot come from the linguistic conventions of a community, which settle on who is a judge, a lawyer, etcetera, but not who is a legal official. 
same reasoning that supports distinction of legal from non-legal rules. For a rule to count among the rules of a legal system, it must be recognized. Yet recognized by whom? Private citizens may conduct what appear to be acts of recognition, but those acts have at most probationary status, awaiting review by officials, as might occur in a situation where private citizens apply legal norms as best they can in the absence of relevant officials. So recognition may come from citizens, but such recognition is not sufficient for validation, which is necessarily conferred by the officials of the legal system. Legal officials, then, are those who are recognized by the officials of a legal system.

Hart also claims, however, that officials of a legal system necessarily "accept" the rules of a legal system, especially its secondary rules, from an internal point of view. Indeed, that the officials of a legal system accept the rule of recognition is one of two minimum conditions necessary and sufficient for the existence of a legal system. ${ }^{11}$ This requirement opens the way to a second, complementary yet separable way to identify officials of a legal system: a descriptive-explanatory theorist might look to see who accepts and practices the secondary rules of recognition, change, and adjudication, conducting this investigation in situa-

11 As Hart puts it in a widely discussed passage:

"On the one hand, those rules of behaviour which are valid according to the system's ultimate criteria of validity must be generally obeyed, and, on the other hand, its rules of recognition specifying the criteria of legal validity and its rules of change and adjudication must be effectively accepted as common public standards of official behaviour by its officials. The first condition is the only one which private citizens need satisfy: they may obey each 'for his part only' and from any motive whatever; though in a healthy society they will in fact often accept these rules as common standards of behaviour and acknowledge an obligation to obey them, or even trace this obligation to a more general obligation to respect the constitution. The second condition must also be satisfied by the officials of the system. They must regard these as common standards of official behaviour and appraise critically their own and each other's deviations as lapses. Of course it is also true that besides these there will be many primary rules which apply to officials in their merely personal capacity which they need only obey".

Hart, The Concept of Law, 2nd. ed., Oxford, Clarendon Press, 1994, pp. 116 and 117. It is worth noting that this view survives concessions in the Postscript to critics of the social rule theory of legal rules and the internal point of view. 
tions where the difference between officials and private citizens is most likely to be starkly evident. Such situations might include those where the application conditions of rules are unclear and officials might be revealed by their practice of stepping forward to set the application conditions or make determinations of the content of those rules. On this approach, officials' identity and characteristic contribution to a rule of recognition is assessed by detection of the presence of a special normative attitude of commitment to secondary rules, and at least obedience of primary or duty-imposing rules.

Introduction of the idea of the internal point of view does a great deal to enhance analytical legal theory's explanatory reach, yet even this addition fails to solve the problem of distinguishing officials from citizens. Two related reasons support this claim. First, private citizens can also accept secondary rules from an internal point of view, as Hart's own argument makes clear. There is nothing structurally incoherent - or functionally unrealistic - in the idea of a private citizen accepting the constitution of her country as supreme law by invoking a right contained in it to challenge a state or provincial law. So while there is undeniably explanatory value in the distinction between internal and external points of view, the distinction is nonetheless insufficient as a means to practical detection or testing for the difference between private citizens and officials. Questions needing answers remain: do citizens who adopt the internal point of view towards their legal system's secondary rules thereby become officials? If not, as we might plausibly suppose, why not? If there is no difference in kind between the attitudes of officials and private citizens, and the difference is instead to be found in something like an accumulation of practice, is there some 'tipping point'?

Second, to the extent that this approach augments rather than replaces the "rules of office" view, it presupposes rather than shows that officials can already be identified by means of rules of office. Since both legal officials and pri- 
vate citizens can accept primary and secondary rules from an internal point of view, it must be that legal officials are those who also occupy a special position in the legal system by virtue of the rules of office. However, as we have seen above, Hart has not provided any adequate account of which rules of office pick out legal officials.

\subsection{Speculative Social Anthropological Accounts}

Some have argued that the circularity of Hart's view is only apparent, and so causes no need for worry. ${ }^{12}$ Such responses typically amount to a denial of the problem by trying to provide a foundation - often in what might be regarded as a 'bootstrapping' approach. Jules Coleman, Kent Greenawalt, and Brian Tamanaha all appear to have taken a route of this sort. Coleman argues, for example, that legal officials emerge as follows:

First, some group of individuals - we do not call them officials and we need not identify them by reference to laws choose to have their behavior guided by a certain rule. In other words, they take the rule as giving them good reasons for action. If that rule takes hold in the sense of establishing membership criteria in a system of rules, and if those rules are complied with generally, and if institutions of certain types are then created, and so on, it is fair to say that a legal system exists. If a legal system exists, then that rule which guides the behavior of our initial group of individuals is correctly described as the rule of recognition for that legal system. And those individuals who guide their behavior by that rule are thus appropriately conceived of as "officials". They are, in a sense, officials in virtue of that rule, but they are not officials prior to it (in either the factual or the logical

12 Coleman's response to a general version of the circularity objection is an indication of the nature and source of the objection - it has been raised in various ways by more than one writer. We believe our setting of the objection is original, yet acknowledge the existence of prior efforts, e.g., in 1988, prior to much of the argument we consider below, Matthew Kramer provided a circularity objection in "The Rule of Misrecognition in The Hart of Jurisprudence", Oxford Journal of Legal Studies, vol. 8, 1988, p. 401. 
sense). Their behavior makes the rule possible, but it is the rule that makes them officials. 13

Coleman's story is not that legal officials are those recognized by other legal officials by means of law, but rather that certain conduct gives rise to rules which in turn identify who is a legal official. On this account there is no circle but instead a kind of social fact explanation of legal officialdom - albeit one which does not arrive with specification on the set of social facts from which it is generated. Similarly, in the course of an exercise in applying Hart's notion of the rule of recognition to the United States, Kent Greenawalt supposes the general populace is sufficiently able to identify legal officials that a foundation can be safely presumed:

At first glance, [Hart's] account may seem to involve a troubling circularity, since officials determine what are the standards of law and they derive their official status from the law. The break in the circle is that one looks to the population at large to see who are recognized as officials. Ordinarily, people's judgments about who are officials may rely on certain assumptions about conformance with legal standards, such as election laws, but people need not understand the complex criteria judges and other officials use to determine what counts as law. ${ }^{14}$

Brian Tamanaha also argues that legal officials can be assumed to have a sufficiently determinate existence, conventionally established:

Remaining with Hart's resort to social practices, the following additional requirement solves the problem of distinguishing legal from non-legal institutionalized systems of normative order: A "legal" official is whomever, as a matter of social practice, members of the group (including legal officials them-

13 Coleman, The Practice of Principle, Oxford, Oxford University Press, 2001, pp. 100 and 101.

14 Greenawalt, "The Rule of Recognition and the Constitution", Michigan Law Review, vol. 85, 1987, p. 624n. 
selves) identify and treat as "legal" officials. Owing to their recognized status as legal officials, their products (generated pursuant to the secondary rules) are treated as 'law'. Systems of primary and secondary rules that are administered by legal officials — so identified - are "legal" systems. Systems of primary and secondary rules that are not administered by legal officials may be institutionalized normative systems, but they are not legall5 [original emphasis].

All three responses, however cautious, are inadequate. Coleman's explanation seems to be close to simply positing a state of normativity as he presumes some historical set of facts corresponding to his description. Does legal order and a cohort of officials in fact arise in the way Coleman supposes? Is this the only way, or can officials ever become officials by request, rather than by "taking power" as his analysis seems to suggest? Coleman's way out of the circularity problem depends on unsubstantiated empirical claims, and reduces the account of officials to a sociological observation rather than a philosophical theory: "the powerful can sometimes become officials". This looks very much like the speculative anthropology Les Green attributes to Hart, and so marks little advance over Hart's construction of Rex I - a construction in which Hart says explicitly that he does not suppose he is describing any actual historical state of affairs. ${ }^{16}$ Yet even if we do accept Coleman's view as a modest advance with respect to explanation of the foundation of a rule of recognition, that advance is insufficient, since it still lacks a general explanation of the nature of officialdom, and how it is to be identified in those other than the "first generation" of officials who gain effective control of power.

Greenawalt's explanation - that officials are to be identified by seeing which persons are recognized as such by the population at large - is similarly fragile. It simply assumes

15 Tamanaha, A General Jurisprudence of Law and Society, Oxford, Oxford University Press, 2001, p. 142.

16 Green, "Legal Positivism", Stanford Encyclopedia of Philosophy online: http://plato.stanford.edu/entries/legal-positivism/, accessed 17 September 2006. 
that such recognition occurs and provides no method for resolution of situations where popular recognition is divided, at odds with officials' self-understanding, or otherwise unsettled. These omissions from Greenawalt's view lead to other troublesome questions. Does the public have the knowledge needed to make this judgment? If the test, to be meaningful, takes as its precondition the existence of a knowledgeable population, what sort of knowledge counts, and how can it be determined if a population is sufficiently knowledgeable? Further, will this actually generate a philosophically satisfying account of officials, or just a snapshot of the perceptions of some group of citizens? Most importantly, are we to conduct some sort of international aggregation in order to reach "the concept of law" as opposed to "American" or "Canadian" or "British" understanding of the nature and identity of legal officials? How are we to avoid parochialism in our theory of law?

Tamanaha's thoroughly conventionalist theory of legal positivism threatens to give up entirely on the pursuit of philosophical explanation of the social foundations of law. Yet if we suppose - as surely we must 1 that in labeling a group of norm-subjects as legal officials, legal officials and the wider group itself we are not doing so willy-nilly, we owe an explanation of the basis of our reasoning. What are the concepts or categories employed, and are they consistent, coherent, and part of an illuminating picture of the social conditions which give rise to law?

While Coleman's, Greenawalt's, and Tamanaha's explanations might avoid the overt circularity of views which suppose that legal officials are simply those persons recognized as such by other legal officials, they leave unspecified -where specification is needed- the connection of their views to sociological, historical, or anthropological observation. Yet even if we accept plausibility of the offered ways to escape circularity, an equally troubling philosophical problem awaits the speculative anthropological approaches: indeterminacy at the core of legality and legal officialdom. On 
Coleman's account, which of the non-circularly determined rules identify who is a legal official and which sorts of activities demarcate legal officials from private citizens? On Greenawalt's and Tamanaha's accounts, according to what non-circularly devised criteria or understanding are legal officials conventionally identified? Are the criteria or understanding coherent, illuminating, and adequate to the task? These unanswered questions demonstrate that the problem of indeterminacy is to elucidate the philosophical concept of a legal official, and that it is a problem which runs deeper than the problem of circularity.

It is important to emphasise at this point that the problem of indeterminacy is not one of simply searching for a line which distinguishes legal officials from private citizens. Such a view supposes that clear criteria already exist, which are in turn compatible with fuzzy borders. Rather, the problem of indeterminacy points to the fact that analytical theories lack an account of the kind or content of roles or powers which serve the theoretical role of distinguishing legal officials from non-officials. In other words, the problem is not just one about looking for determinate, hardedged categories for sorting particulars representing contentious borderline cases, but rather positive criteria for choice of particulars to be explained at all, far prior to finding and facing borderline cases.

Perhaps part of the stubbornness of the problem of indeterminacy can be attributed to the fact that the notion of an "official" is not unique to law. While rules of office identify judges, lawyers, and so on, rules of office also identify university presidents, bank managers, and National Hockey League referees - sometimes in very confusing ways as the rules of sports such as rugby are explicitly named "laws". ${ }^{17}$ Interestingly, private citizens also seem able to create rules of office. Often private citizens contract to create personal

17 See, for example the Laws of Rugby as set out by the International Rugby Board at: http://www.irb.com/EN/Laws+and+Regulations/Laws/. Accessed September 20, 2006. 
or private security guards, whose professional obligations are to enforce, among other things, legal rules against theft and assault. Indeed, in many modern legal systems, citizens have a legally recognized power of arrest, and exercises of such a power can be treated as state actions. ${ }^{18}$

Whatever the probative value of these remarks on the factors complicating explanation of the role of officials in constituting legality, problems remain for proponents of an approach which assumes Hart's picture of an official-operated rule of recognition resting at the foundations of legal order. Which officials are legal officials? What costs are incurred by a theory dependent on an account of legal officials when circularity and indeterminacy characterize the theory's attempts to solve at more than an intuitive level the problem of demarcating legal officials from other norm subjects? These questions remain unresolved, we contend, on the representative approaches adopted by Hart, Coleman, Greenawalt, and Tamanaha.

\section{An InTER-Institutional THEORY}

Preceding argument sets the challenge and standard to be met by any supplement to analytical legal theory's approach to legality. If we are right and the official-based approach is beyond repair, a new approach must at least avoid the meta-theoretical-evaluative vices of circularity and indeterminacy, while providing a positive theoretical account of the distinguishing characteristics of legality. Whatever the content of the positive account, it must amount to more than an abstract version of familiar practices, justified post facto via narrow bootstrapping from some imagined past situation. The resulting account of legality must, among other virtues, be able to explain the novel prima facie legal phenomena we surveyed in the first part of our paper. We shall also count as a virtue of our approach its consistency with 
the experience and understanding of ordinary citizens while sound theory may sometimes require revision of some intuitions, accounts of social phenomena are preferable to the extent that they make sense of our experience in terms which resonate with our pre-theoretical reflective understanding of that experience.

We have described our response to this challenge as an "inter-institutional theory". Our approach is rooted in an account of institutions, and relations amongst groups of institutions which deserve to be regarded as legal. Since this approach involves a potentially unfamiliar recombination of elements already evident in other jurisprudential writing, it may be useful to have a quick prospectus in hand for reference as the argument unfolds. Perhaps the quickest way to situate our approach is in terms of its experiential point of departure, and the contrast between that point and Hart's view. Hart famously sets out in The Concept of Law from the understanding of modern municipal law available to the ordinary man. Part of the contention of this paper has been that this departure point is no longer what it was. Even while we remain sympathetic to Hart's meta-theoretical-evaluative commitment to theorizing in ways comprehensible by private citizens, the changing experience of life under law compels us to start our explanatory work at a different point. Our ordinary citizen travels much more than Hart's citizen ever did, and our ordinary citizen finds norms in families, or perhaps bunches or clusters, operated by institutional owners of varying authority, from schools to Greenpeace to the British Airport Authority to the UN Security Council and Disneyland. Legality and legal norms have a particular practical force in the ordinary citizen's life, but their nature and force is not, we contend, best understood by searching for ladders or chains of authority for particular norms. Rather, a spatial metaphor seems better suited: in the complex web of norms of various kinds encountered by private citizens, legal norms represent a kind of upwelling of normative force, especially forceful standards 
clustered around particular kinds of life events, relatively stable normative reference points in a context of constant competition amongst norms. How then can we account for what is distinctively legal, the particular upwelling of normative force which occurs in states, in intra- and extrastate forms, often in systemic fashion, but sometimes only in proto-systemic fashion?

Our account is based in what is common to the experiences sketched above, the ordinary citizen's encountering prima facie legal norms not one by one as seen in Hart's gradual expansion of a notional primitive society's form of social order, but in clusters oriented around institutional purposes and functions. Institutions, on our view, contain various kinds of norm-subjects holding under varying conditions powers to use institutionally-owned norms. Our account of systems of norms will rely on elaboration of an idea mentioned in the introduction, that of intensity of mutual reference among institutions and their norm-users. Departing from citizens' experience of webs of norms leads us to discuss powers, institutions and systems in general terms first, with exemplary reference to legal institutions and systems. We will then approach the key problem - finding grounds for demarcation of legal norms, institutions, and systems from other forms of normative social order. We ground our ascription of legality to the institutional normative system characteristic of the law-state via re-use of the only content restriction Hart places on the cluster of norms at the heart of an enduring legal system - the minimum content of natural law. The resulting view enables us to capture the primus inter pares nature of the law-state as a manifestation of legal order, while recognizing nonetheless the legality of non-state bodies claiming authority to issue content-independent peremptory norms. These beginnings of an analytical alternative to the official-based account of legality will then be tested against the task of understanding the place of the law-state. 


\subsection{Legal-Normative Powers, Institutions of Law and Legal Institutions}

While available space prevents us from elaborating fully the nature of normative powers, enough can be said here to begin to support an alternative to the official-based approach to legality and identification of legality's border. Normative powers can be distinguished along two general dimensions: type and force. Within the dimension of type and focusing on familiar legal-normative powers, we follow Joseph Raz in asserting three overlapping but conceptually distinct categories of normative power: ${ }^{19}$ powers to determine, alter, and enforce legal-normative situations. Within the dimension of force, there are also three overlapping but conceptually distinct categories: legal-normative powers can differ in terms of scope of norm-subjects affected, duration of their exercise, and assertion of institutional force. Analysis of legality in terms of legal-normative powers leads to a kind of matrix view of the interaction of those legalnormative powers. This view recognizes the very wide range of possible combinations of legal-normative powers of several types and varying force, operated by a range of normsubjects from judges to private security guards and incorporated bodies. It also supports the observation that legalnormative powers can come in many different varieties used by various norm-subjects, which explains why the official/ non-official divide is insufficiently sensitive to be of much explanatory use in locating the source and borders of legality (We will leave for the moment the question of how to distinguish legal from non-legal normative powers, since that argument requires the next section's elaboration of what we mean by institutions wielding powers).

Discussion of legal-normative powers demonstrates the complexity of the normative web in which officials and others live, but it does little to demarcate distinctively legal areas of that web - we have simply added to our descrip-

19 Raz, The Authority of Law, Oxford, Clarendon Press, 1979. 
tive-explanatory armoury the notion of normative powers of various kinds. Achievement of that task requires, on our view, attention to the institutional context in which officials, non-officials, part-time officials and so on wield normative powers. This focus on approach to context or system rather than individual norm-subject or class of norm-subject is of course not new. Social network theorists have for more than fifty years sought to illuminate complex social situations by looking beyond the history of agents who sit as "nodes" in "networks", inquiring instead into the relations and exchanges between nodes. ${ }^{20}$ Aspects of this analysis can be usefully transferred to assist characterization of legality and its borders with other social norms, viewing legality's nodes as those institutions whose inhabitants (including but not limited to officials) relate to other institutions via operation of the diverse sorts of legal powers (and obligations, etcetera) we have briefly discussed.

Since legal institutions are at the heart of our view, we should clarify the sense of 'institution' we use, distinguishing it from its general sense in ordinary language and multiple senses in law and legal theory. Other institutional theorists such as Neil MacCormick have made sustained use of the idea of institution in explaining practices characterized as institutions of law, such as contract, declaratory judgment, and criminal law. ${ }^{21}$ An institution of law, on MacCormick's view, may be viewed as encapsulating a legal doctrine comprised of a cluster of related norms which united serve a single or limited number of purposes. This institutional cluster of norms may be used in various areas of life under law, often within organizations confusingly labelled "legal institutions", which persist over time while operating some range of social functions recognized as "insti-

20 The locus classicus is Barnes, J., "Class and Committees in a Norwegian Island Parish", Human Relations, vol. 7, 1954, pp. 39-58.

21 MacCormick, Neil and Weinberger, Ota, An Institutional Theory of Law: New Approaches to Legal Positivism, Dordrecht, Kluwer, 1986, and MacCormick, Neil, Institutions of Law: An Essay in Legal Theory, Oxford, Oxford University Press, 2007. 
tutions of law". Both quite different uses of "institution" rely for their intelligibility on reference to wider social notions of institutions. For example, the 'institution' of contract and the "institution" of queuing at bus stops share reliance on shared conceptions of a desirable social function performed by coordinated practices with generally recognized prompts and responses enabling operation of the function. Similarly, the idea of institution as a normative, function-oriented organization incorporating a cluster of complex normative practices such as contract or queuing transfers readily to the legal context from additional social contexts. Courts are readily understood as normative, function-oriented institutions, as are primary schools, the Red Cross, and the Scouting movement.

General discussion of social institutions must also face the question we left behind in our discussion of normative powers: how to get from institutions qua complex practices and institutions qua clusters of complex practices to an account of institutions of law and legal institutions. Escape from problems of circularity and indeterminacy hampering the official-based account of legality is not enough. We must make sense of (i) the distinctive role of institutions of law as sources of normative inputs to practical reasoning as special authoritative sources of special rights, claims, obligations, etcetera. distinguishable from the wider class of institutions of social fact. A defence of insanity in a criminal law system, for example, is an institution of law, while raising one's hand in class is not. What are the identity conditions of legality which mark the difference? We need additionally (ii) some way of distinguishing legal institutions from other normative social institutions such as churches and fraternal organizations. Accounts of (i) and (ii) are clearly related: as analytical legal theorists rightly maintain, it is not possible to distinguish institutions of law or legal norms from other institutions or norms by means of the content of individual institutions or norms. Rather, the 
legality of institutions of law is constituted by their connection to or practice by legal institutions.

The accounts, then, ought to be interdependent in their focusing simultaneously on the identity of institutions of law and legal institutions. Yet it is surprising to note that while institutional theorists have rich accounts of institutions of law, relatively little has been said about the identity of legal institutions. For example, after providing a sophisticated account of institutions of law in terms of institutive, consequential, and terminative rules, MacCormick says this about social institutions:

Tedious though the reasoning which leads to the definition [of institutions of law] is, it is important that we should have defined the term clearly. For there is another use of the term "institution" which is also of great importance in relation to the law, but which is quite different from the well-established lawyer's notion of a "legal institution" which I have just explicated. There are certain types of social system or sub-system, such as universities, schools, hospitals, orphanages, libraries, sporting organisations and the like, to which we often refer as "institutions". These are organisations of people which retain their organisational identity through time even though their personnel may change, because they are getting on with some job, and getting on with it in an organised way. Such I shall call "social institutions". To this class it is obvious that courts, parliaments, police forces, civil service departments, the Faculty of Advocates, and the Law Society, all belong. These are of course, social institutions which exist to perform legal functions, hence the possibility of confusion with the concept "institution of the law". 22

There is much of interest in the second sense of institution qua "social system or subsystem", and much depends on its explanation and identity conditions as an explanatory tool amounting to more than a synonym for "system". 
In particular, if we are to take the performance of legal functions understood as institutions of law as the criterion for selection of legal institutions from among the wider class of social institutions, several questions then need answers: what is it about the 'organised' performance of legal functions understood as institutions of law that gives rise to legal institutions? Can legal institutions overlap via shared institutions of law? How can we assess the edges or boundaries of legal institutions? Admittedly, some of these questions concern atypical instances of legal institutions, so we need not answer them all immediately. Yet even a rudimentary inter-institutional account of legality and legal system must engage the central question of how core or typical legal institutions amount to a legal system, so we now turn to that question via a deeper account of legal institutions and their interaction.

\subsubsection{Legal institutions: a deeper account}

It is tempting to define a legal institution by following one of the usages reported in Black's Law Dictionary -and consistent with MacCormick's view identified in the quotation above- which characterizes a legal institution such as a government department as an agglomeration of institutions of law. On this understanding, a legal institution represents topic-specific deployment of institutions of law peculiar to its legal-institutional focus, together with supporting institutions of law capable of use in various legal contexts yet given specific content and distinctive practice in application to the legal institution's topic-specific purposes. For example, in Canada the federal Department of Fisheries and Oceans qua legal institution deploys institutions of law specific to fisheries management, yet additionally uses in special form institutions of law with multiple forms of application given special expression in the context of fisheries and oceans, e. g., injunctions. As a description of legal institutions and their use of institutions of law this sketch is likely 
unobjectionable to many analytical legal theorists to the extent that it is more or less a re-description of elements of the analytical account, albeit at a higher level of organization. Yet as an account of the emergence and borders of legality the circularity of this view is plain. The legality of institutions of law is traced to their interconnected use by legal institutions, yet legal institutions are identified as an agglomeration of uses of institutions of law. The problem of indeterminacy is also present. Do legal institutions have special functions or features which support a criterial or content-derived way of distinguishing them from other social institutions? In other words, do legal institutions have a special subject-matter? The challenges of circularity and indeterminacy force us to supplement the picture presented so far.

\subsection{Grounding Legal System: Mutual Reference and Intensity}

An account of the system-constituting nature of legal institutions relies on an understanding of 'system.' There are of course a wide range of understandings of the notion of system, sub-system, and so on. For our purpose in providing a contribution to the general part of a theory of law, a broad and general understanding of system will suffice, at least until we assess whether it can bear the weight of our explanation of the special character of a legal system. Drawing from an intuitive understanding of system familiar from talk of social systems as diverse as legislative assemblies, teams, religious communities, or voluntary associations, let us abstract an explanation of social system as a composition of interdependent parts related by mutual reference with respect to some shared focal activity (sometimes a very broad focus), occurring at some threshold of intensity. Social systems of various kinds can be captured by this broad definition - a school system, for example, is a system by mutual reference of its education-focussed 
schools (which contain institutions of teaching, head- or principal-ship, student study and conduct, parental participation, and so on) with a certain intensity in exchange of information (and sometimes persons) related to those institutions, for example curriculum, budgets, student results, athletic teams and so on. While it may be impossible to specify minimum thresholds of intensity of mutual reference in the abstract, which will no doubt vary from one context to another, it is nonetheless clear that such thresholds exist in the sense that there are clear examples of recognition of non-systems and collapsed systems, from the dissolution of sports leagues due to persistent failures to communicate matters such as scheduling, to collapses of school systems attributed to a lack of leadership connecting institutions within and among various schools.

\subsection{Grounding Legal System: Minimum Content of Natural Law}

In keeping with our institution-focussed approach, the preceding discussion of mutual reference and intensity is still one step removed from both discussion of particular norms and the legality of those norms. Since we see institutional interaction as the core of legality, we focus on explanation of that phenomena, while recognizing that the identity of individual contributing institutions and norms (and persons using powers to wield norms) remains analytically available as a matter of subdivision of networks of legal institutions. It remains nonetheless to get past our somewhat elusive discussion of social systems having some shared focal activity, and on to an account of the shared focal activity of legal systems. ${ }^{23}$

Here we propose to employ a radically underutilized feature of Hart's view of legal system: the minimum content of

23 And they cover the special ground in a special way - by providing/recognizing powers to introduce, determine, and enforce legal-normative situations. 
natural law thesis. ${ }^{24}$ Hart famously argues that given certain logically contingent but naturally necessary features of human and social life, any legal system must include basic rules restricting the free use of violence, securing property, and enforcing promises. Without such content, a legal system cannot hope to persist or provide support for any other rules. There are at least two reasons why the minimum content of natural law thesis has not served, as we think it can, as a general feature which helps identification and distinction of legal systems from other social systems. First, attention has been unfortunately concentrated on the question of whether Hart's admission of a minimum content of natural law reveals that his legal positivism is untenable, despite his argument to the contrary. ${ }^{25}$ Second, Hart misleadingly avoids describing the thesis as a conceptual claim, opting instead to explain it as a "natural necessity"; it is only a fact about legal systems because of the nature of humans and social life as they are, and so it is conceptually possible to imagine legal systems which do not need such content. The upshot of identifying a natural necessity is that it implies that the claim is not part of a conceptual theory of law and legal system, which only includes necessary or conceptual truths about law. However, this view of what is properly included within a conceptual theory of law and legal system is mistaken. As we have suggested above and can argue only partially here, a descriptive-explanatory account of law and legal system as a contribution to the general part of law ought to include amongst its virtues identification and illumination of the features of the phenomena by which ordinary citizens understand them. These features may comprise either necessary features or contingent relations or most likely both. While it is useful to test the conceptual reaches of concepts by imagining logically possible worlds, what is more important for theories of

24 Hart, op. cit., n. 11, pp. 193-200.

25 See, e. g., Lon Fuller, The Morality of Law, rev. edn., New Haven, Yale University Press, 1964, pp. 154-5. 
legality and legal system which value accuracy in description of social reality is that they account for how those in life under law understand their experiences.

We intend to use Hart's minimum content of natural law thesis as it was intended, as a generally observable feature of legal systems which identifies a core ${ }^{26}$ subject matter or content of law. In our account, relations of mutual reference between social institutions give rise to legality and legal system of the kind associated with the law-state when the objects or contents of those relations combine to cover, via operation of diverse kinds of legal-normative powers, these minimum conditions of social life. Notice, then, that it is not possible to demonstrate the legality of any particular legal institution by isolating attention to its particular purpose or function. Legality only emerges from the web of interactions of legal institutions which aim at least at securing a minimum content of natural law. ${ }^{27}$ Other forms of legality may be acknowledged under this view, but they tend, on our account, to have what might regarded as "subsystem" qualities, better understood on our spatial metaphor as upwellings of legality lacking the core content characteristic of legal systems concerned with foundational elements of legality. It might be helpful, following our metaphor, to view non-systemic upwellings of legality as clusters of legal institutions, a kind of legal order analogous to legal system and composed sometimes of identical kinds of parts, but in no sense properly regarded as necessarily a developmentally primitive version of a proper legal system. Severing system from legality is crucial to this picture, both as a matter of accurate theoretical reflection of forms of intra-state legality, and, as we shall see, to reflection on the nature of the connection between law and state which constitutes the familiar term "law-state".

26 Though suitably abstract, since the necessary rules may and do themselves vary in particular content.

27 As well, on our view the idea of an individual source of law, such as a court or legislature, is incoherent. Legality is systemically constituted by special interaction between institutions. 
It might naturally be asked at this juncture how we have evaded circularity and indeterminacy, and what has taken up the explanatory role previously played by officials. On our view, officials retain an important though reduced role in an explanation of legality and legal system to the extent that they are among the operators of institutions of law. Their theoretical importance is decreased by our focus on legal institutions within which officials are but one kind of norm-subject and operator of institutions of law since ordinary citizens asserting, e. $g$., constitutional rights might also from time to time (so irregularly) operate institutions of law in legal institutions. Moreover our focus on the intensity of interaction between legal institutions as the driving force of legality and a constitutive element of legal system gets out from beneath the search for logically primitive units of legality from which a picture of system might be found. Instead we have posited a conceptual scheme which may be tested for adequacy against the explanatory needs of inquirers, the meta-theoretical-evaluative virtues of sound descriptive-explanatory theory, and the capacity of the theory to address suitably generalized social phenomena - we offer, after all, a contribution to general jurisprudence, and not a test or roadmap for construction of successful legal system. So our approach aims, as Hart did, to provide a universal concept of law while recognizing the variability of human experience in particular conceptions of law. Our approach nonetheless avoids the indeterminacy problem since we posit within our explanatory scheme the minimum content of a legal system together with a conceptual account of the reach of the system in its characteristic incorporation of the authoritative, content-independent peremptory norms within institutions of law in turn within legal institutions. Since those legal institutions mark the end point of our search for legality, any remaining battle over the edges of legality and legal system will come not at the level of the question of who counts as an official, but in highly local and particular arguments regarding the suffi- 
ciency of the intensity of mutual reference among social institutions exhibiting the conceptually necessary features of legal institutions.

\section{Legality and the De-CEnTRED LaW-State}

With an understanding of legality and legal system in hand, we can return to our original motivation in seeking to establish an alternative to a Hart-derived approach to legality and legal system: the rise of novel prima facie legal phenomena.

We identified in section 1 above some of the phenomena associated with arguments regarding the "de-centring" or "hollowing out" the state, additionally visible in familiar phenomena from the rise of international humanitarian law to unprecedented harmonization of standards for, e. g., information and financial exchanges. However one measures, states today are far more inter-related and inter-dependent than a century ago, much as Hart observed in 1961 in argument contra Austin that absolute autonomy was not then, and long had not been a realistic expectation of state conduct. Yet while socio-legal theorists are correct to dislodge the conceptual association between law and the state, we contend that they are mistaken to endorse legal pluralism in its place. Our inter-institutional account of legality provides the basis for argument that the relation between legality and states is logically contingent, and empirical accounts of intra- and inter-state activity reveal that the assertion of logical contingency is born out in fact. In other words, inter-institutional interaction, and not state activity, best explains what is spoken of as the legality of municipal, transnational, and international law, all without falling into pluralism or awkward metaphorical distinctions of 'soft law' from 'hard law' and so on.

One particularly vivid way to demonstrate the contingency of the connection between legality and states is to contrast a familiar analytical explanation against the inter- 
institutional view we have set out. In The Concept of Law Hart explains how the rule of recognition specifies and ranks diverse sources of law, allowing a detached observer to assess the membership of any putative member-rule of the system by pulling on a chain of validity. Consider Hart's illustration:

The sense in which the rule of recognition is the ultimate rule of a system is best understood if we pursue a very familiar chain of legal reasoning. If the question is raised whether some suggested rule is legally valid, we must, in order to answer the question, use a criterion of validity provided by some other rule. Is this purported by-law of the Oxfordshire County Council valid? Yes: because it was made in exercise of the powers conferred, and in accordance with the procedure specified, by a statutory order made by the Minister of Health. At this first stage the statutory order provides the criteria in terms of which the validity of the by-law is assessed. There may be no practical need to go farther; but there is a standing possibility of doing so. We may query the validity of the statutory order and assess its validity in terms of the statute empowering the minister to make such orders. Finally, when the validity of the statute has been queried and assessed by reference to the rule that what the Queen in Parliament enacts is law, we are brought to a stop in inquiries concerning validity: for we have reached a rule which, like the intermediate statutory order and statute, provides criteria for the assessment of the validity of other rules; but it is also unlike them in that there is no rule providing criteria for the assessment of its own legal validity. ${ }^{28}$

Hart was simply illustrating operation of the rule of recognition and clearly did not intend this illustration as a formulaic account of legal system, yet it is nonetheless inadvertently misleading.

There is, in particular, a misleading suggestion of a hierarchical structure of legal validity in Hart's talk of an ultimate rule of recognition and a chain of legal reasoning.

28 Hart, op. cit., n. 11, p. 107. 
While this style of presentation might have some virtue as a clear and intuitive sort of summary, contemporary social reality seems rather more complex. The sources of legal validity are not foundational in the sense that there is an ultimate criterion - such as "whatever the Queen in Parliament enacts is law" - which give all the other subordinate criteria and rules their validity. Or if there is such a criterion, its existence is at best a notional summary, since it can never be specified beyond assertion that it emerges from the shared co-operative activities of officials - whose identity cannot be specified in a non-circular way. This hierarchical view also disregarded the extent to which the activities of the Oxfordshire County Council, just as much as the activities of the Ministry of Health and Parliament, give rise to the emergence of law. Legality, in this situation, is to be found within and among the web of interactions of diverse institutions, and is therefore not reducible to the activities of any particular institution.

This re-explanation seems especially plausible when advanced beyond the state of affairs described by Hart in 1961. Space limits us to taking up just one of the varieties of prima facie legal phenomena we set out in section 1 to unsettle the official-based approach. Let us consider the example of the Greenland Conservation Agreement. The agreement, whose central object is a content-independent peremptory norm prohibiting commercial salmon fishing in Greenland's territorial waters, was signed and is practiced by three non-governmental organizations on the recommendation of a scientific council. The connection of the agreement to any state recognition or systemic authorization is tenuous at best, as it has only been recognized by the devolved government of Greenland which has agreed to "help enforce it". On the standard analytical picture, then, the agreement lacks legality, since it lacks official recognition by state authorities whose practices create the core and borders of legal systems. As we suggested in our initial diagnosis, such an account seems to under-emphasize the 
nature of the agreement: several institutions have deliberately created and now enforce a content-independent peremptory norm governing the use of natural resources.

Given the possibility of trans-state institutional normative practices which are not adequately explained by state-centred legal theories, one might be tempted by the legal pluralist suggestion: if one wants to achieve a truly general jurisprudence one must recognize that (i) law can exist in several different forms, and (ii) no single form ought to be given explanatory priority. We are now in a position to see why the pluralist suggestion can be rejected: if legality, both within states and beyond them, is inter-institutionally created, and not reducible to the activities of a hierarchy of state authorities, we can see that transnational or even international legality, contra the socio-legal theorists, is not fundamentally different in kind from municipal legality, which differs in focal content only. Where legality exists, it exists because it is constituted by inter-institutional interaction which covers special ground in a special way. In all of this we have suggested that the notion of system might be retained for law-states, in recognition of their focus on activities core to enduring human social life. We recognize, however, that retention of the title of "system" is largely a nod to convention, familiarity, and the particular prominence of the law-state in the web of norms in which we all live. Legality is separable from the state, both conceptually, and unfortunately, empirically, as what are lately called 'failed' or 'rogue' states fulfill the conditions of statehood on the back of a fear-based rule which lacks the attributes of legality and systemic legality.

\section{CONCLUSION}

Anyone advising adoption of a novel approach to legality and legal system faces a stiff challenge. The presently dominant theories are typically dominant for good reason, and challengers must have still better reasons to advocate 
change. The inter-institutional theory we present arrives on the back of argument identifying what we believe are insuperable circularity and determinacy problems at the foundation of the official-based analytical approach to legal system. Our inter-institutional account rebalances the analytical approach by providing a system-level explanatory counterpart to the persuasive norm-level account of legality already offered by analytical legal theorists. Perhaps most importantly, we have attempted to bring our theory to bear on emerging social phenomena which analytical legal theories must encounter but have not yet engaged thoroughly. Our theory is, as we claimed at the outset, still in a rudimentary phase, yet all theories must have a beginning, and the inter-institutional theory now has its beginning.

\section{BIBLIOGRAPHY}

BARNES, J., "Class and Committees in a Norwegian Island Parish", Human Relations, vol. 7, 1954.

Coleman, Jules, The Practice of Principle, Oxford, Oxford University Press, 2001.

DiCKSON, Julie, "How many legal systems?: some puzzles regarding the identity conditions of, and relations between, legal systems in the European Union”, Problema, this issue.

FULLER, Lon, The Morality of Law, rev. edn., New Haven, Yale University Press, 1964.

GREEN, Leslie, "Legal Positivism", Stanford Encyclopedia of Philosophy online: http://plato.stanford.edu/entries/ legal-positivism/.

GreenaWALT, Kent, "The Rule of Recognition and the Constitution", Michigan Law Review, vol. 85, 1987.

HART, H. L. A., The Concept of Law, 2nd. ed., Oxford, Clarendon Press, 1994. 
KRAMER, Matthew, "The Rule of Misrecognition in the Hart of Jurisprudence", Oxford Journal of Legal Studies, vol. 8, 1988.

MACCORMICK, Neil and WeINBERGER, Ota, An Institutional Theory of Law: New Approaches to Legal Positivism, Dordrecht, Kluwer, 1986.

- - Institutions of Law: An Essay in Legal Theory, Oxford, Oxford University Press, 2007.

—_, Questioning Sovereignty, Oxford, Oxford University Press, 1999.

RAZ, Joseph, The Authority of Law, Oxford, Clarendon Press, 1979.

TAMANAHA, Brian, A General Jurisprudence of Law and Society, Oxford, Oxford University Press, 2001. 